Chioma Opara

Chioma Opara, is Professor in the Institute of Foundation Studies, Rivers State University of Science and Technology, Port Harcourt, Nigeria. Email: cachiom@yahoo.co.uk
Tribute

\section{Buchi Emecheta (1944-2017): Beyond the dingy ditch}

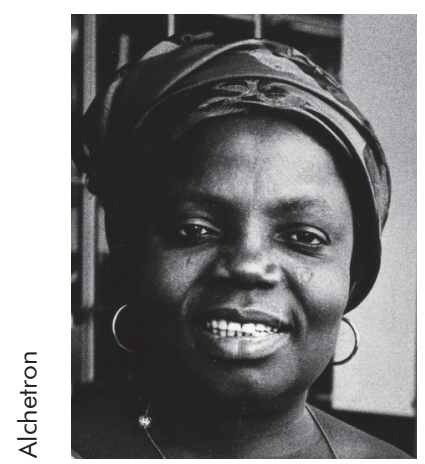

Nwanyi ka ibeya ana $-a !^{1}$

The media have in the past weeks been awash with the sudden demise of a great female writer, activist and publisher-Buchi Emecheta-on 25 January 2017 in London. Nigerians and, indeed, scholars all over the world have not yet recovered from their shock at the loss of two Nigerian literary giants, Elechi Amadi and Isidore Okpewho, only recently in 2016. And now another fatal blow has been dealt on the literary sphere at the dawn of a brand new year. It may be necessary to note that Buchi Emecheta passed on the heels of Isidore Okpewho's death (an interval of just four months). Both were, incidentally, from Delta State. In fact, the three deceased writers-Amadi, Okpewho and Emecheta came originally from the oil-rich Niger Delta region of Nigeria.

Much as I was not privileged to meet Buchi Emecheta in flesh, nevertheless, I have over three decades continually perceived her giant strides and heard her stentorian voice on the pages of her books. I have been particularly fascinated by this amazing woman who baldly and boldly told the story of her life in some of her novels. Not only are her stories very compelling, her "racing, no nonsense, chatty style" is patently enthralling. There can be no doubt that she was an acculturated and emancipated Nigerian woman living in London. Essentially, she is the first African writer to dare render the private very public in her autobiographical works where she superbly melds the "granite of facts" with the "rainbow of dreams".

Florence Onyebuchi Emecheta was born on 21 July 1944 in Lagos, Nigeria. From very humble beginnings, she strove to acquire Western education in a monolithic, colonial society where preference was flagrantly given to the education of the male child. She migrated to London in 1962 in order to join her husband, Sylvester Onwordi. Primed, assertive, diligent and resilient, the young wife and mother encountered sexism, capitalism, racism and domestic abuse in the course of her myriad struggles for autonomy. In her diminishing capacity as a second class citizen in Metropolitan London, she was accordingly mired in the dingy ditch of stifling darkness and ultimately emerged with her head far above water. Her first and second 
novels, In the Ditch (1972) and Second Class Citizen (1974) respectively, as well as her autobiography, Head above Water (1984), attest to her travails in an utterly hostile environment. At the age of twenty-two, Emecheta was constrained to divorce her husband who had not only relentlessly battered her but also burnt the first manuscript of her novel, The Bride Price (1976). The single mother of five young children remained undaunted as she set out to attain her goals. Where Virginia Woolf had craved a room of one's own, propitious for artistic productions, the nurturing and essential mother, Emecheta, yearns for a room of her own and her children who have, obviously, constituted the Muse for her prodigious creativity. Such are the real joys of motherhood! An uncommon inspiration such as this, begot a harvest of publications by the distinctly talented writer. Among her numerous works are: sixteen novels, one autobiography, three plays, three children's literature and six articles. In the vein of Virginia Woolf's Hogarth press and Flora Nwapa's Tana press, Buchi Emecheta's publishing house Ogwugwu Afor has been quite relevant to some of her literary outputs.

The themes in her works include gender violence, child marriage, virginity cult, objectification of womanhood, sexual harassment and nation building. She discussed the Nigerian civil war in her historical novel Destination Biafra (1982) and also authored a science fiction, The Rape of Shavi (1983). A thorough iconoclast, Emecheta deconstructs retrogressive traditional values with a tinge of sarcasm, mordant irony, scintillating wit and acerbic humour. She debunks the cultural myth of woman as slave and she simultaneously unmasks the deflated postcolonial male in his enslaved posture. Clearly, the slave motif traverses her early works. Physical, cultural and metaphysical forms of slavery intersect and bog down her vulnerable protagonists. The slave master in The Slave Girl (1977) is redolent of the ruthless slave masters on the Southern plantations in Harriet Jacobs' Incidents in the Life of a Slave Girl (1861). Impelled by sexual politics, the revisionary writer flays a culture that condones any aspect of female enslavement, distorting the oeuvre of her oral foremothers who have obviously influenced her, she revises the status of the fulfilled woman. In the light of this, she lauds the achieved status of "the dignified single women". Garbed in this cloak, she comes back to Nigeria as a visiting professor at the University of Calabar. This is graphically etched in her partly autobiographical novel, Double Yoke (1982). It is palpable that this is the legendary return of the hero. A survivor of numberless battles, she brims with pride and exudes ample confidence as she flaunts the varied accoutrements of success.

A great achiever, Buchi Emecheta, earned a number of awards, honours and recognition: Dubbed a Nigerian-born British novelist, she is deemed the first successful black woman novelist living in Britain after 1948. She, with Flora Nwapa was included in Margaret Busby's Daughters of Africa: An International Anthology of Words and Writings by Women of African Descent (1992). Again her magnum opus, The 
Joys of Motherhood (1979) was listed among Africa's 100 Best Books of the Twentieth Century selected at the 2002 Zimbabwe International Book Fair. Her fourth novel, The Slave Girl won the Jock Campbell Award from The New Statesman in 1978. She was on Granta magazine's 1983 list of Best of Young British Novelists. She obtained a PhD from the University of London in 1991. She was awarded an Honorary Doctorate of Literature from Fairleigh Dickinson University in 1992. She was in 2005 invested with the Order of the British Empire (OBE).

Samuel Johnson posits that, "Life affords no higher pleasure than that of surmounting difficulties, passing from one step of success to another, forming new wishes and seeing them gratified." The dynamic and iconic writer, Buchi Emecheta, has glaringly ridden the rough waves, weaved through the tortuous twists and turns and finally emerged triumphant in her hallowed capacity as a radiating Leading Light on the rocky terrain of African feminism.

Agunwanyi!?

You charged, you roared, you bestrode the world!

Adieu!

\section{Endnotes}

1. A woman of world stature has departed!

2. Lioness in the path! 